\title{
INVENTING SACRED PLACES: WOODEN SCULPTURES AND PLACEMAKING OF CONTEMPORARY LANDSCAPE
}

\author{
Mare Kõiva \\ Estonian Literary Museum \\ e-mail:mare@folklore.ee
}

\begin{abstract}
This article describes some characteristics of modern vernacular architecture as placemaking models and presents the biographies of two monuments - the energy pillars. The paper also examines the connection between the concept of earth power and the cosmopolitan views of earth energies. These monuments are used to highlight the religious, folkloric, and healing potential. In the expository part, I shall address the attitudes towards the structures and discuss to what extent they can be regarded as creative innovations.
\end{abstract}

Keywords: energy pillars, geopathia, new religious movements, placemaking, wooden monuments

\section{Introduction}

Placemaking in public spaces uses institutional support, official permits, and resources for beautifying the surroundings. The majority of the wooden sculptures and monuments installed in Estonian public space since the 1980s have been designed by artists, although examples of vernacular art do exist. Wooden 
sculptures have been created as part of placemaking in the urban (suburban) environment. At the same time, wooden sculptures have also been installed on private lands without any institutional backing. This paper examines wooden sculptures - energy pillars, which have been created since the 1990s and are consecrated with an initiation rite as places of special power. The most wellknown examples include the large wooden pillar in Otepää, southern Estonia, and the one in the Tuhala karst area near Tallinn.

Materiality and placemaking have been examined in anthropology, folkloristics, and in religion studies for approximately thirty years (Mazumdar \& Mazumdar 2006; Orsi 1999; Vásquez \& Knott 2014; Sofield et al. 2017). Sofield remarks that placemaking as a result of a community-led organic process invents emic, organic, folkloric, and community-driven initiatives that differ markedly from the formal 'industry' of place-making. Tourism-related outcomes are explored even where tourism was not a primary motivation (Sofield et al. 2017: 2). This standpoint also suits Estonian cases.

This article describes some characteristics of modern vernacular architecture and the placemaking model and presents the biographies of two monuments. These are used to highlight the religion-related practices concerned with material objects and their religious and folkloric potential. We can trace new explanations of earth power as well as the invention of cosmopolitan teachings of earth energy in local culture. In the expository part, I shall address the attitudes towards the structures and discuss to what extent they can be regarded as creative innovations.

To characterise the wooden sculptures or monuments, it should be mentioned that the societal meaning of wooden sculptures is somewhat different from that of metal and stone monuments - these clearly stand for mental and symbolic values rather than events or persons. The past can also be interpreted as mythical, reconstructed, and folkloric. Sculptures have a number of functions: they are used to decorate and structure spaces/environments, they carry folkloric, mythical or religious meanings, while statues are expressions of vernacular architecture and markers of mixed religious expressions. Their production is cheaper and faster, but they need considerable care - their age is short. They are necessary for performing ritual practices, which is one of their many functions (in more detail see Kõiva 2017; Kivari 2016). 
Wooden Sculptures and Placemaking of Contemporary Landscape

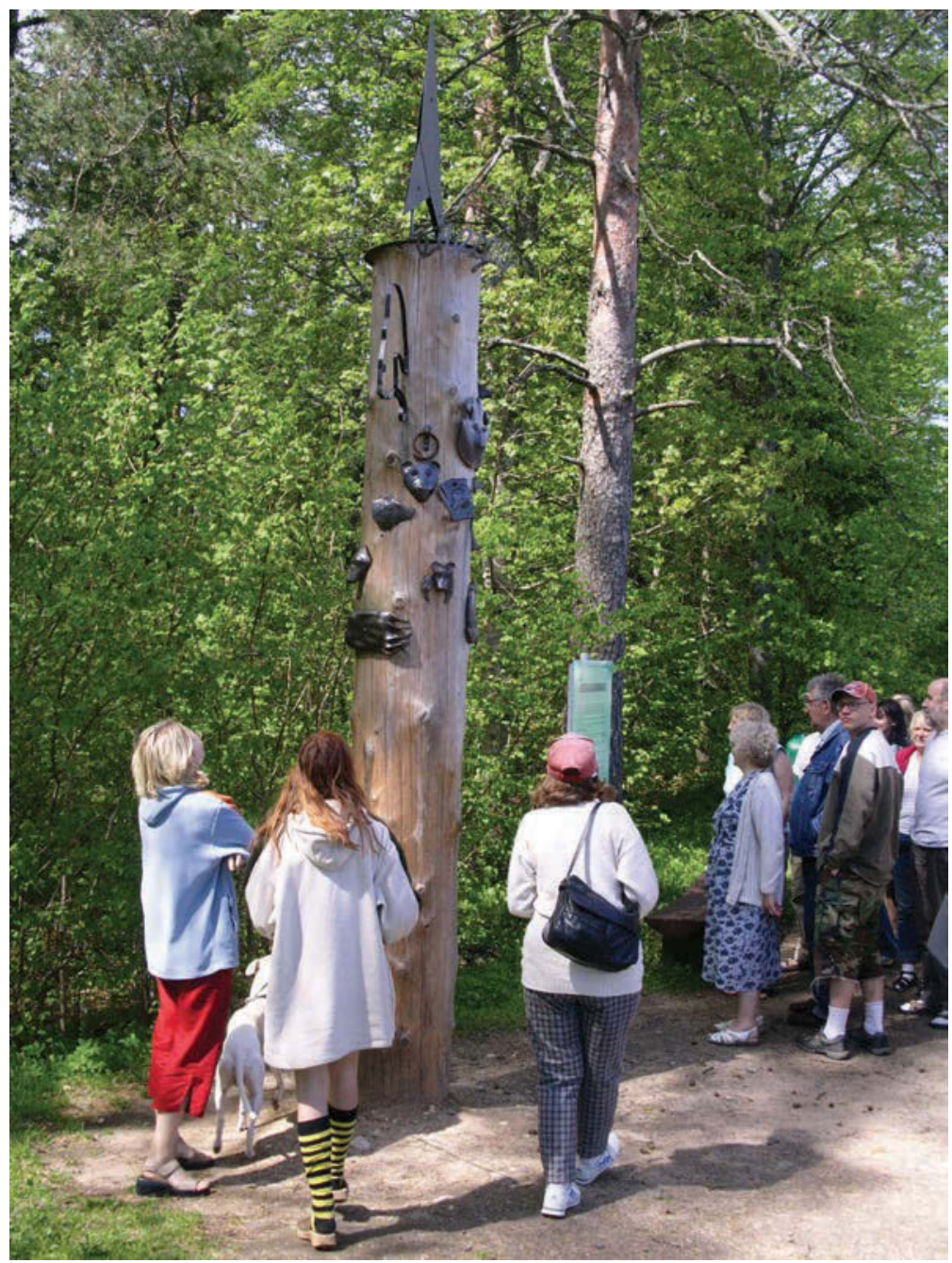

Otepää Energy pillar. Photo Andres Kuperjanov 2005. 


\section{Method}

The method used for this research was folkloristic. Several data collection techniques were employed to collect data; observations were made of the physical environment of the wooden monuments. People and their activities were studied by means of participant observation and interviews. Data was recorded in the form of field notes, photographs, and video recordings as well as by examining newspapers and websites. This paper is part of a larger ongoing study of sacred spaces (both private and public).

\section{Short Historical Background}

Dowsing is one the oldest methods and was still common in the early 20th century. This was, above all, necessary for finding good water sources for wells, but dowsing rods were also used for locating mineral resources or treasures. According to ethnologist Ants Viires, dowsers of previous centuries sometimes wore special clothing, and their experiences during dowsing were close to altered states of consciousness and unconsciousness (Viires 1986). Dowsing rods were not the only method for locating groundwater - hidden aquifers were given away by differences in vegetation, unusually coloured or shaped plants, and other natural signs (see Skriptoorium). Unlike in the Western European tradition, the $18^{\text {th }}-19^{\text {th }}$-century Estonian calendar literature and popular publications did not address locating treasures with dowsing rods (cf. Estonian calendars 1739-2015).

The trajectory of changes in earth power / earth energy-related folklore and belief practices cannot be clearly defined on the basis of current knowledge. Still, it is clear that throughout time their focus for these practices has been on health, followed by other aspects. In older folklore records we can trace the concept of earth power - earth, beer, milk, etc. had power). Many important knowledge popularisation activities have been carried out via lectures by and practices of mediums and healers, which have helped to establish a newer belief layer regarding dangerous earth energy, spatial points, and sleeping above an aquifer as a health risk: 
Buildings, especially residential buildings, must not be built on still aquifers, because you cannot get a good rest sleeping on top of them and this may lead to many illnesses (Koppel 2011).

In the 1990s, the increasing use of dowsing rods and frames led to the emergence of hobbyists and professional service providers who helped to determine the location of aquifers and dangerous areas in living quarters and buildings, find places with beneficial properties for storage facilities, locate places with favourable conditions for growing plants (see Skirptoorium), and diagnose people's health status and illnesses. The spectrum of health problems and indicators diagnosable or measurable via this method came to include the intensity of stress and depression, lesions, chronic diseases, tumours, blood pressure and blood count, but also the intensity of intrapersonal relationships and their failure (Kõiva 1993).

One of the new notions introduced into the heath and pendulum market was the idea of an invisible energetic grid that occurs on the Earth's surface a concept formulated by German physicist Ernst Hartmann (1915-1992). Hartmann spread his ideas through various publications in the 1950s and 1960s, of which Krankheit als Standortproblem (1954) was central. According to his theory, these magnetic-like lines form a regular grid around the Earth, along compass lines at a distance of approximately two metres; the negative effect they exert on living in a particular place is the reason for a higher rate of mortality in that place. According to various printed and oral materials, sleeping or working at the location of a Hartmann's knot causes problems with health and technology and can even prove to be fatal (Kõiva 1993; Kivari 2016). Rein Koha, a professional doctor, not only investigated Hartmann's net in medical environment, but also initiated experimental investigations. As a new approach, people began to determine the healing properties and functions of old cultic sites and offering stones in particular (Kõiva 1993), which was followed by the establishment of new sites.

On his website, Energoman (2018) provides the following summary of everything that concerns buildings: This is certainly due to constant urbanisation and buildings being built right next to one another. These days, you can safely say that 40-60\% of people have built their homes in areas with unfavourable energy fields. This study was concerned with Estonia, but I am certain that it is the same in other countries, especially in Europe and the U.S., where people constantly 
enter new site fields or remain in such areas only partially. The 'energetic' layer of religious/new spiritual lore is concentrated around the concept of certain places that embody an unexplainable power that has a strong impact on the mental and physical wellness of a human as well as on plants and trees. Energy columns are reported to be situated at geological breaks (meaning they occur due to peculiarities of the earth's surface) or in churches and other sacred places. The forces that can be detected around the columns are often related to magnetism, electricity or just 'fields'.

The entrenchment of teachings and practices in everyday life requires the existence of a certain critical number of practitioners and communal activities. Since the 1980s, people with similar skills and worldviews have joined the Estonian Geopathic Society. The conferences of the society have served as interdisciplinary forums with a broad scope, where representatives of different research fields hold discussions and share their knowledge of the topic in the form of academic presentations (cf. Koha 2006, 2009; Kivari 2016). The society's activities were endorsed by academician Anto Raukas; the fact that it is part of an academic institution - the Institute of Geology - created an interesting social dialogue which brought together academic and intuitive research. Raukas' personality and charisma served as a unique guarantee of credibility not only to the pendulum community but also to other extrasensory disciplines.

In the next chapter I discuss, by examining the history of two sites, the process leading from the previously mentioned colourful practices to the explanation behind specific energy columns and the installation of wooden pillars on sites charged with energy.

\section{The History of the Otepää Energy Column}

The area of Otepää in southern Estonia is an ancient settlement site and rich in historic landmarks. In ancient times, Otepää hillfort featured a stronghold of the Estonians from Ugandi County, where they successfully fought invading crusaders and Russian armies from the $11^{\text {th }}$ to the $13^{\text {th }}$ century. Otepää had an important role in the Estonian national independence movement. On 4 July 1884, pastor Rudolf Kallas consecrated the first Estonian flag in Otepää Church. During the Soviet period, this picturesque area served as a training site of the Soviet ski team. The most notable events of the independence period include 
a visit by the leader of the Tibetan people, His Holiness the $14^{\text {th }}$ Dalai Lama Tendzin Gyatso on 3 October 1991, during which he blessed Lake Pühajärv and reportedly visited the future site of the energy column. The historic visit is commemorated by a wooden sculpture on the edge of Pühajärve Park, which faces the lake.

A monument celebrating the existence of positive energy fields was unveiled in Mäe Street on 1 October 1992. The upper part of the more than two-metretall wooden pillar, erected in the energy field, features twelve forged-iron bear figures. The erection of the pillar was initiated by the then Mayor Jaanus Raidal (born 1967), who was one of the founding members of the Estonian National Independence Party, established in 1988, and joined the green movement in the same year. He became a member of the parliament in 1992.

The entire field is surrounded by benches, and the location of these as well as the column itself was selected by psychics. The energy column is a symbol that reminds us that in this rapidly changing world, humans are a part of nature and everything is based on the rules of nature, which rely on balance and codependency. The Wikipedia entry for Otepää says the following:

The city is home to Otepää Church. Next to the church there is a monument commemorating soldiers killed in the Estonian War of Independence and an energy column (Wikipedia; cf. Oidra 2017).

The energy column makes the location unique - there are no similar sculptures in our neighbouring countries. As a result of the media fame, a holiday house of the same name has been opened near the column:

The Energy Column Holiday House is located in a quiet area. The famous energy column is just across the road. Come and relax in an energetically charged and empowering location! You will have the use of four rooms and a cosy fireplace lounge on the ground floor of the building (Energiasamba puhkemaja).

In the summer of 2003, the column fell over and was replaced by a new one with the help of craftsmen from Otepää. Riho Karu, Deputy Mayor of Otepää rural municipality, confirmed to the media that the column, which had been erected more than a decade ago, was completely rotten in the inside. The energy column was given to local craftsmen, who restored it within a few weeks (BNS 2003). The 
article triggered a brief discussion on social media and in comments sections, but tourists and other people who happen to come across the column are not interested in the polemics on its authenticity.

\section{The History of Tuhala Witch's Well and Energy Pillar}

Tuhala Witch's Well is located in a karst area in northern Estonia (in Kose rural municipality in Harju County). There are eleven prehistoric settlements and three burial cairns in the vicinity. The area features several notable natural/ man-made monuments - approximately thirty offering stones with small depressions, the sacred Kataveski juniper and four supposed sacred sites. The local non-material cultural heritage that dates back to the $19^{\text {th }}$ century is also noteworthy with its legends about witches, witch doctors, and sages. These narratives form the bases for the contemporary history of placemaking. Legends are supported by the popular name for Tuhala rural municipality, Nõiavald, which roughly translates as 'witch's realm' (Kallasmaa et al. 2017 [2016]). Today, the main attraction in Tuhala is the so-called Witch's Well, which begins to overflow during times of high water when the flow rate in the Tuhala River is at least 5,000 litres per second, making the well 'boil over' up to 100 litres of water per second. The well provides brownish, yet clean, bog water.

Behind the advertisement of the phenomenon is a local man, Ants Talioja, the head of Tuhala Nature Centre, who is an expert on local folklore. He has written the books in order to highlight the special significance of local folklore (cf. Talioja 2002). Ants Talioja began advertising the site using folklore and the phenomenon of the Witch's Well, but it is generally known that the well was already a sightseeing destination in the 1970s. A few decades later, in 2001, mediums located an energy column there, which was then featured in several media channels:

Estonia's most powerful energy pillar was discovered next to the Witch's Well in 2001. The energy column (as it is commonly called) is a stream of electromagnetic radiation that is expelled from the Earth's crust via a vertical limestone passage. These often occur in karst areas as $50-80 \mathrm{~cm}$ circles. Tuhala energy pillar has a very strong magnetic field. The oak pillar erected next to the Witch's Well marks the exact location of the 
positive energy column. An equally powerful column is located in a cave in Lourdes, France (Post 2001).

Folklorist Kristel Kivari, who has studied the phenomena of Tuhala and Kirna Manor (Järva County), highlights Rein Hanstein as one of the first mediums and the discoverer of the energy column, and refers to influential dowser Rein Weber's ${ }^{1}$ role as the developer of the spirituality of Tuhala as well as the advertiser of the location (Kivari 2016).

As the next logical step, Tuhala was advertised as a special healing place. New rituals started to be performed at the site and the number of tourists increased (see Kõiva 2017). The national television channel ETV traditionally reports the overflowing of the Witch's Well as a special event in the news. People come to see this phenomenon in buses and cars, making Tuhala a popular place to observe high water in spring. Aside from the Witch's Well, attention has also been drawn to the energy pillar, other energetic sites, and the ritual conducted on site. The whole complex has been featured both in Estonian and via international media (BBC News, Herald Tribune).

In conclusion, we can see that this significant contemporary site was shaped by a number of people, but the long history of the place is once again important - it is located in an unusual natural landscape - a karst area. The energy pillar and the media contributed to the combined effect of the above. The site became a popular tourist attraction thanks to its natural environment, traditions, spirituality, and esoteric nature.

\section{Site Efficiency and the Multitude of Opinions}

Eric Hobsbawm distinguishes between three types of invented traditions, each of which has a distinctive function: a) those establishing or symbolising social cohesion and collective identities, b) those establishing or legitimatising institutions and social hierarchies, and c) those socialising people into particular social contexts. The first type has been most commonly referred to and often taken to imply the two other functions as well (Hobsbawm \& Ranger 1983: 9). In the case of Tuhala, the emphasis is put on socialising people into a social context.

The next stage takes us to the efficiency of the site: people often discover other sites with healing properties and locate places where specific groups of 
illnesses can be treated. Talioja shares stories about the beliefs regarding Tuhala, which vary from reports of diseases going into remission to miraculous recovery narratives. The proportion of information mediated by storytellers and the recipients of their stories varies to a great degree and in the following text, it is somewhat unclear whether Talioja recounts other people's (Weber's?) opinions or whether journalist Jõgeda is referring to previously published media texts:

Ants Talioja tells a story of a lady who came to see the columns with a tour group and was back at six o'clock the next morning. "Three hours later, there was a crack in her ear - and she could hear again." Dowsers assure that people with radiculitis and rheumatism and those who are impotent or infertile should find relief here (Jõgeda 2007).

One of the most detailed pendulum demonstrations featured in the media was conducted by Rein Weber, who talked about what could be healed at Tuhala:

Hepatitis? The pendulum only shows $10 \%$ on the map. It is practically useless for treating this. Flu? Now this you can probably heal. Schizophrenia? Practically zero. Pneumonia? It doesn't help. Cancer? It could have a positive effect. Gynaecological diseases? The pendulum does not move in the case of infection. The pendulum begins to move once Weber stops to think what illness to name next. Headache? Very little. Impotence? See, the pendulum moves, so it could be beneficial. Female infertility? See, it moves again (Heinla 2001).

Ants Talioja's own position is represented in interviews given to the media within a longer period of time, as well as in media appearances and video clips that demonstrate how he has progressed from being a local history enthusiast to believing in energy fields. In later interviews he refers to renowned specialists, the expert opinions of powerful mediums, and the participation of academics in determining the location, and shares his opinions about what happened. In these interviews Talioja is certain his personal energy is so great that the column cannot cause damage to him. A video filmed in educational style features Talioja and interviewer Kalju Paldis (biogeodesist) when sharing their experiences in sensing energy: [y] ou need to put your left or right hand near the oak log; if you feel warmth, cold, heaviness or a tingling sensation, it is an energy column [---] - Tuhala has an energy field so strong that your hands 
tingle all the time. However, if you pull back, you will face another energy field (Energiasambad Tuhala nõiakaevul 2012).

Even though energy fields and energy pillars received fewer comments than exciting health topics (reactions are mainly triggered by fresh news stories), these discussions display a colourful range of opinions. The general attitude towards energy pillars is positive:

VAHO (February 13, 2017)

For people passing by it's just a column. For those who are close to nature and love hugging trees, it can be a place to get some energy.

\section{Gitapandit (December 4, 2015)}

Amazing positive energy can be felt and gathered and one is cleansed by just being there. There is a board with guidelines telling you what you should do to receive and feel the energy.

At the same time, people are seeking answers to questions whether the phenomena exist, why they work, and to what extent they work:

Ligeia (29.10.2005, at 17:35)

I was wondering how many of you believe in the changing or healing powers of energy or whether someone has personally felt something near the energy column? - I didn't feel any warmth or cold, even though I was told I should have. I did get a splitting headache. Perhaps people have different reactions to energy. What is your general view on the New Age movement?

Nevertheless, it is clear that sceptics report every setback online as evidence of things not working and of false teachings. When the first wooden pillar in Otepää fell over, commentators were not interested in the fact that wooden sculptures and pillars do not last long in the Estonian climate. Instead, they presented their own views on this phenomenon:

Hari Matus (19.07.2003 15:30)

If the column is a source of energy, then you'd have to be able to use it to light a lantern, a light bulb or even a simple light diode, whereas Eesti Energia should not make money from this energy. The words of these energy column nuts will continue to be seen as a lack of natural science education until they manage to light such a lamp. Their secondary school 
diplomas should be withdrawn and they should be sent back to school to study physics.

Harsh criticism sometimes forces those who believe in energy columns to renounce or hide their opinions:

"You relax, close your eyes and put your hands on it," the singer said, explaining how to absorb cosmic energy. The scepticism of interviewer Mihkel Raud with regard to the powers of the aforementioned log even made Marten doubt himself (Anonymous 2011).

\section{Discussion}

The use of wooden sculptures has a long history: the oldest surviving wooden sculpture covered in symbols is 2.8 metres tall and 7,000 years old, and it is preserved in a museum in Yekaterinburg in Russia. Pillars are also very common in history: Indian iron pillars with inscriptions date from the beginning of the calendar era. Historic examples include the Wolferchampton pillar in England, the tribal candles of Erzyans and Mokshas, woodhenges in Durrington, and other locations. Maypoles, which are still erected in European countries today, have a similar shape. Wooden sculptures of Norwegian and Slavic deities date from later centuries and flourish in contemporary wooden art.

H. Whitehouse and R. McCauley (2005) stress that despite the heterogeneity, there are similarities in religious materiality. The individual cases discussed indicate that the structure of different sites and the dynamics of creating a religiously important place are subject to a certain standardisation. Most members of a certain group create mental representations using forms that are roughly similar - experts use simpler forms. They begin with structures whose concepts are known to be found in various places in the world.

Previous examples show that the third important characteristic of placemaking is connecting the site to ancient times and/or a colourful history. What is also notable is the recreation and introduction of wooden sculptures of spirits and fairies. Vernacular wooden sculptures created by artists feature a similar form. For instance, one of the stereotypical examples of sculptures is the figure of a long-haired, bearded male spirit. Sculptures are often decorated with 
magical symbols. The stereotype can be observed in examples of sculptures from different regions in Europe - the artistic language and mental models used are the same. The incorporation of fairy tales with fictional characters, nature/ecology, and history is also interesting. Thirty-six wooden sculptures depicting Estonian fairy tale characters and fairies were installed along the Small Nature Energy Trail, taking into account energetic places. Sculptures of fairy tale and fictional characters can also be found in urban environments, but their incorporation into specific healing and balancing places mainly happens at special ritualistic sites.

Although folkloric wooden sculptures are usually installed in places with positive energy, negatively charged sites are sometimes also marked. Healing places with wooden sculptures of different characters to sit on can be found both in public spaces and on private land. A good example of this is the Wood Crone family park in southern Estonia (Kõiva 2017: 210).

One significant aspect of modern placemaking is wilderness/nature, the social and symbolic value of which is very important to urbanised people. The meaning of nature is expressed not only in forests, but also in individual trees, green areas, urban water bodies, and other things that relate to nature. Over time, the preservation of the natural environment and its protection from intensive management has brought together people with different worldviews in Estonia to participate in protests and engage in active defence as well as raise petitions where necessary. When a mine was planned in the TuhalaNabala Nature Reserve, people rallied to protect local nature and its symbol, the Witch's Well. More than 65,000 signatures were collected in defence of the place, but cultural protests were also powerful. One of the examples was the song "Nõiakaevu loits" (Incantation of the Witch's Well) composed by Urmas Sisask, which was performed by eleven well-known rappers and pop, rock, and choral singers (Eesti tähtede ühislaul 2010).

An important part in the body of data related to the invention of sacrality is the creative process based on worldview, which can at least partially be described by Csikszentmihalyi's (1996: 8) model of creativity, where creativity occurs as a result of the concurrence of three main components: personal development and its background, cultural domain, and social field (companions, critics, teachers, and the elite). This definitely characterises both the song "Nõiakaevu loits" and the practice of marking useful places with sculptures. However, the society can both support and curb the development of creativity. 
Valuable ideas can be found in the theory of social anthropologists Tim Ingold and Elizabeth Hallam, which argues that people act in a space between novelty and conventionality and are forced to improvise, because there are no systems of codes, norms or rules that can predict every situation (2007: 2).

An important factor is adaptation and changes in the main concepts. The main explanatory model claims that energetic places are dangerous but pillars are not. The knowledge and interpretations vary - here we can see how places with enormous energy are marked with a pillar.

Research on the modern monuments of Northern Europe in Estonia has shown that such wooden monuments were tools for the social and symbolic construction of the world. The integration of the monuments into the surrounding landscape, the incorporation of the mythological/fairy tale/fictional figures into the monuments, and replication of older architectural figures has constituted an essential part of the contemporary placemaking process as well as that of inventing sacrality.

\section{Acknowledgements}

This study is connected with Estonian-Bulgarian bilateral project "The Balkan and Baltic Holiness - Modern Religiosity and National Identity", and is related to research projects IRG 22-5 and TK-145.

\section{Notes}

1 Rein Weber (1940-2018) - Estonian architect, graduated from the State Art Institute of the Estonian SSR in 1965 and from Sorbonne University (Civilisation française) in 1979. He was a geobiologist and a dowser.

\section{Archival Sources}

Skriptoorium - Digital Archives of the Department of Folkloristics, ELM.

Estonian Calendars 1739-2015. 


\section{References}

Anonymous 2011. Marten Kuningas vaimustus Otepää energiasambast [Marten Kunigas Was Fascinated of Otepää Energy Pillar]. Delfi, 30.09. Available at http://kroonika.delfi.ee/news/muusika/marten-kuningas-vaimustus-otepaaenergiasambast?id=58827856, last accessed on 28.08.2018.

BNS 2003. Otepää energiasammas kukkus ümber [Otepää Energy Pillar Fall Down]. Delfi. Available at http://www.delfi.ee/teemalehed/otepaa-energiasammas, last accessed on 28.08.2018.

Csikszentmihalyi, Mihaly 1996. Creativity: Flow and the psychology of discovery and invention. New York: Harper Collins.

Eesti tähtede ühislaul - Tuhala Nõiakaevu loits 2010 [Song of Estonian Stars Incantation for Tuhala Witch Well]. YouTube. Available at https://www.youtube. com/watch?v=qAcACOEC_Pc, last accessed on 28.08.2018.

Energiasamba puhkemaja 2017. Puhka Eestis [Vacation in Estonia]. Available at https:// www.puhkaeestis.ee/et/energiasamba-puhkemaja, last accessed on 28.08.2018.

Energiasambad Tuhala nõiakaevul [Energy Pillars at the Tuhala Witch Well]. Loov Maatriks. YouTube. Available at https://www.youtube.com/ watch? $\mathrm{v}=\mathrm{cJHktivWErQ}$, last accessed on 28.08.2018.

Energoman 2018. Harmoonias ümbritseva keskkonnaga ja loodusseadustega [In Harmony with Environment and Laws of Nature]. Available at https://energoman.ee/ kontakt, last accessed on 28.08.2018.

Heinla, Eve 2001 Tuhalas asub võimsaim energiasammas Eestis [In Tuhala Locates the Most Powerful Energy Pillar]. Õhtuleht. Available at http://www.ohtuleht.ee/109350/ tuhalas-asub-voimsaim-energiasammas-eestis, last accessed on 28.08.2018.

Hobsbawm, Eric \& Ranger, Terence (eds.) 1983. The Invention of Tradition. Cambridge: Cambridge University Press.

Ingold, Tim \& Hallam, Elizabeth 2007. An Introduction. In: Elizabeth Hallam \& Tim Ingold (eds.) Creativity and Cultural Improvisation. Oxford, UK: Berg, pp. 1-24.

Jõgeda, Tiina 2007 Eesti uus turismihitt - energiasammas [New Hit in Estonian Turism Energy Pillar]. Eesti Ekspress. Available at http://ekspress.delfi.ee/kuum/eestiuus-turismihitt-energiasammas?id=69126949, last accessed on 28.08.2018.

Kallasmaa, Marja \& Saar, Evar \& Päll, Peeter \& Joalaid, Marje \& Kiristaja, Arvis \& Ernits, Enn \& Faster, Mariko \& Puss, Fred \& Laansalu, Tiina \& Alas, Marit \& Pall, Valdek \& Blomqvist, Marianne \& Kuslap, Marge \& Šteingolde, Anželika \& Pajusalu, Karl \& Sutrop, Urmas 2017. Eesti kohanimeraamat [Estonian Place Names]. Tallinn: Eesti Keele Sihtasutus.

Kivari, Kristel 2016. Dowsing as a link between natural and supernatural. Folkloristic reflections on water veins, Earth radiation and dowsing practice. Dissertationes folkloristicae Universitatis Tartuensis. Tartu: University of Tartu Press. 
Koha, Rein 2006. Radiatingbiosphere and fields of Earth, related architecturalgeometryofforms and theirenvironmental psycho-physical influence on organisms: abstracts and articles: international seminar at Käsmu, June 15-18, 2006. Käsmu: Geopathic Society.

Koha, Rein 2009. Radiating fields of Earth, related architectural geometry of forms and their influence on organisms: abstracts and articles: international seminar in Tallinn, June 11-14, 2009. Tallinn: Geopathic Society.

Kõiva, Mare 2017. Constructing Contemporary Periodical and Occasional Rituals. In: Ekaterina Anastasova \& Mare Kõiva (ed.) Balkan and Balticum. Current Studies in the Postsocialist Space. Sator 18, pp. 199-222. Tartu: ELM Scholarly Press. DOI: 10.7592/Sator.2017.18.

Kõiva, Mare 1993. Teadja: Rein Koha [Sage: Rein Koha]. ERR archives. Tallinn: ERR.

Koppel, Margit-Mariann 2011. Energiasammas - looduslik akulaadija [Energy Pillar Natural Battery Charger]. Kultuur ja elu, 2005, No. 2. Available at http://kultuur. elu.ee/ke480_energiasambad.htm, last accessed on 28.08.2018.

Lefebvre, Henri 2009. State, Space, World. Selected essays. Minneapolis-London: University of Minnesota Press.

Mazumdar, Shampa \& Mazumdar, Sanjoy 2006. Hindu temple building in Southern California: a study of Immigrant religion. Journal of Ritual Studies, Vol. 20 (2), pp. 43-57.

Oidra, Katrin 2017. Eestimaa põnevad väepaigad, mida tasub sel suvel külastada [Adventurous Power Places in Estonia, to Visit This Summer]. Postimees, 01.07. Available at http://alkeemia.delfi.ee/mystika/esoteerika/eestimaa-ponevadvaepaigad-mida-tasub-sel-suvel-kulastada? $\mathrm{id}=78744576$, last accessed on 28.08.2018.

Orsi, Robert A. 1999. Gods of the city: Religion and the American urban landscape. Bloomington, IN: Indian University Press.

Post, Eda 2001. Energiasammas võib vähist terveks ravida [Energy Pillar Can Heal Cancer]. Postimees, 18.07. Available at http://www.postimees.ee/1880037/ energiasammas-voib-vahist-terveks-ravida, last accessed on 28.08.2018.

Sofield, Trevor \& Guia, Jaume \&Specht, Jan 2017. Organic 'folkloric' community driven placemaking and tourism. Tourism Management, Vol. 61 (August), pp. 1-22, Available at https://doi.org/10.1016/j.tourman.2017.01.002, last accessed on 28.08.2018.

Talioja, Ants 2002.Tuhala nõia lood. [Witch Lore from Tuhala]. Tallinn: Varrak.

Vásquez, Manuel A. \& Knott, Kim 2014. Three dimensions of religious place making in diasporaa. Global Newtworks, Vol. 14 (3). Special Issue: The religious lives of migrant minorities: a multi-sited and transnational perspective, pp. 326-347. Available at https://doi.org/10.1111/glob.12062, last accessed on 29.01.2019.

Viires, Ants 1986. Kaevutargad [Well Sinkers]. Keel ja Kirjandus 5, pp. 294-297.

Whitehouse, Harvey \& McCauley, Robert N. 2005. Mind and Religion: Psychological and Cognitive Foundations of Religiosity. Walnut Creek: AltaMira Press. 